\title{
Climate influences on Guiana dolphin diet along the Brazilian coast
}

\author{
Gabriel M. Rupil ${ }^{1,2}$, Juliano André Bogoni ${ }^{2,3}$, Lupércio Barbosa ${ }^{4}$, Milton César C. Marcondes ${ }^{5}$, \\ Ana Paula Cazerta Farro ${ }^{1}$ \\ ${ }^{1}$ Programa de Pós-graduação em Biodiversidade Tropical (PPGBT); Centro Universitário Norte do Espírito Santo \\ (CEUNES); Universidade Federal do Espírito Santo (UFES). PC 29932-540, Bairro Litorâneo, São Mateus, Espirito Santo, \\ Brazil. \\ (GR) (Corresponding author) E-mail: gabrielrupil@ gmail.com. ORCID iD: http://orcid.org/0000-0002-0693-3456 \\ (APCF) E-mail: farro.ana@gmail.com. ORCID iD: http://orcid.org/0000-0002-3536-1653 \\ ${ }^{2}$ Programa de Pós-graduação em Ecologia (POSECO); Universidade Federal de Santa Catarina (UFSC); Laboratório de \\ Mamíferos Aquáticos (LAMAQ), PC 88040-900, Trindade, Florianópolis, Santa Catarina, Brazil. \\ ${ }^{3}$ Universidade de São Paulo, Escola Superior de Agricultura "Luiz de Queiroz", Laboratório de Ecologia, Manejo e Con- \\ servação de Fauna Silvestre (LEMaC), Piracicaba, São Paulo, Brazil. \\ (JAB) E-mail: bogoni.ja@gmail.com. ORCID iD: http://orcid.org/0000-0002-8541-0556 \\ ${ }^{4}$ Organização Consciência Ambiental - Instituto ORCA. PC: 29101-300, Vila Velha, Espírito Santo, Brazil. \\ (LB) E-mail: lupercioabarbosa@gmail.com. ORCID iD: http://orcid.org/0000-0002-5091-1844 \\ ${ }^{5}$ Instituto Baleia Jubarte (IBJ). PC 45900-000, Caravelas, Bahia, Brazil. \\ (MCCM) E-mail: milton.marcondes@ baleiajubarte.org.br. ORCID iD: http://orcid.org/0000-0003-0100-118X
}

\begin{abstract}
Summary: The Guiana dolphin (Sotalia guianensis) is a small-bodied dolphin distributed along the Atlantic coast from Honduras to southern Brazil. It preys on fish, squid and shrimps. Several seminal studies have described its diet, yet relationships between the species' feeding plasticity and climate gradients remain unknown. We compiled a large database of Guiana dolphin stomach remains from southeast coastal Brazil. We described the species' diet using a number of descriptors, multivariate analysis of variance to test possible differentiation in diet composition, and the Morisita index to estimate the extent of trophic niche overlap between groups. We also analysed feeding plasticity using a regression tree analysis followed by an ordination analysis. We present new records of prey for the species in Brazil. Our results suggest that the Guiana dolphin has opportunistic feeding habits, which may exhibit the species' feeding plasticity. Such feeding plasticity is associated with the capability to prey throughout a wide array of climate conditions. From a conservation ecology perspective, we conclude that estuaries - even ones that are over-depleted and succumbing to human impacts—are paramount environments for the Guiana dolphin, serving as important sources of prey for the species and other sympatric marine mammals.
\end{abstract}

Keywords: feeding plasticity; Guiana dolphin; estuary; regression tree; climate variability.

Influencias climáticas en la dieta del delfín costero del litoral brasileño

Resumen: Sotalia guianensis es un delfín de pequeño porte cuya área de ditribución abarca el litoral atlántico desde Honduras hasta el sur de Brasil. Al día de la fecha, pese a que la dieta de este delfín ya ha sido descrita en anteriores trabajos, las posibles relaciones entre la ingesta de determinadas presas y los cambios en las variables ambientales aún se ignoran. En nuestro trabajo, describimos la dieta de estos delfines a través del análisis de contenidos estomacales y recopilamos una extensa base de datos a efectos de desvendar posibles patrones en la ecologia trófica de la especie a lo largo de la costa atlántica sudoriental brasileña. Usamos un conjunto de descriptores para caracterizar la dieta de estos delfines, probamos posibles diferencias por medio de un análisis de variancia multivariada y cuantificamos el grado de solapamiento trófico entre grupos utilizando el índice de Morisita. Además, analizamos la plasticidad trófica de la especie por medio de un árbol de regresión seguido de una ordenación. Presentamos nuevos registros de presas para la especie en Brasil. Los principales resultados que obtuvimos confirman los hábitos oportunistas que caracterizan a estos delfines y evidencian que sus presas más frecuentes y abundantes son a su vez abundantes en estuarios, como peces pertenecientes a la familia Sciaenidae. Dichos hábitos oportunistas podrían estar relacionados con la característica plasticidad trófica de la especie. Corroboramos que la plasticidad trófica del delfín costero se debe a su capacidad de predar en un amplio rango de condiciones climáticas, aunque sus presas más comunes se encuentran en estuarios. Desde el punto de vista de la Ecología de la Conservación, concluímos que los estuarios son ambientes de relevante importancia para estos delfines y otros mamíferos marinos simpátricos, por ser éstos una importante fuente de recursos alimenticios, aunque están en ambientes que soportan un fuerte impacto antrópico.

Palabras clave: plasticidad trófica; delfín costero; estuario; árbol de regresión; variables meteorológicas.

Citation/Como citar este artículo: Rupil G.M., Bogoni J.A, Barbosa L., Marcondes M.C.C., Farro A.P.C. 2018. Climate influences on Guiana dolphin diet along the Brazilian coast. Sci. Mar. 82(3): 159-168. https://doi.org/10.3989/scimar.04775.27A 
Editor: D. Oro.

Received: March 9, 2018. Accepted: September 21, 2018. Published: September 29, 2018.

Copyright: $\odot 2018$ CSIC. This is an open-access article distributed under the terms of the Creative Commons Attribution 4.0 International (CC BY 4.0) License.

\section{INTRODUCTION}

The Guiana dolphin (Sotalia guianensis, van Benédén, 1864) is a small-bodied Odontocetus within the Delphinidae family popularly known as boto-cinza in Brazil. It is distributed continuously along the Atlantic coast of Central and South America, from Honduras $\left(15^{\circ} 58^{\prime} \mathrm{N}\right)$ to Norte Bay $\left(27^{\circ} 35^{\prime}\right)$, Santa Catarina State, Brazil (Da Silva and Best 1996, Simões-Lopes 1988). It inhabits coastal and shallow waters, protected estuaries and bays. The species typically occurs associated with runoffs and may occasionally be found upstream to the limit of tidally influenced waters (Da Silva and Best 1996).

Over the last few decades, several studies have given insights into the feeding ecology of the Guiana dolphin along the Brazilian coast (Pansard et al. 2011, Cremer et al. 2012, Lopes et al. 2012). However, further studies may provide valuable information about the Guiana dolphin's feeding habits. The identification of potential prey species consumed by the Guiana dolphin can help to unveil predator-prey relationships, which in turn can enhance our understanding of the ecological role of dolphins in marine ecosystems (Pauly et al. 1998), taking into consideration likely intra- and interspecific trophic overlap and population dynamics (including top-down effects).

Although the Guiana dolphin feeds primarily on fish, it also occasionally consumes cephalopods and shrimps (Flores and Da Silva 2009). Sciaenid fish species appear to be the most common fish prey consumed by this dolphin species along the Brazilian coast (Lopes et al. 2012). Recent studies have also described the feeding ecology of the Guiana dolphin from the Abrolhos Bank (Rodrigues 2014). Moreover, there is evidence supporting the opportunistic feeding behaviour of the Guiana dolphin in Neotropical marine waters (Di Beneditto and Siciliano 2007, Daura-Jorge et al. 2011, Lopes et al. 2012). However, the likely underlying relations between the dolphins' diet and changes in climate variables remain poorly understood.

Here, we compiled a fairly large database regarding the Guiana dolphin's stomach content samples surveyed off the southeast coast of Brazil, an area that shows heterogeneous environmental and climate characteristics, allowing us to explore the influence of climate conditions on Guiana dolphin diet variation. Our database may be one of the largest samples of Guiana dolphin stomach content ever analysed in Brazil. In order to describe the feeding ecology of this species, we analysed diet composition by examining stomach content with the aim of (i) evaluating the rank of each prey species consumed by the dolphin; and (ii) exploring the dolphin's feeding ecology along the Brazilian coast according to spatiotemporal changes of climate features. We hypothesize that the Guiana dolphin is able to prey over a large array of species, may show dietary plasticity over space and time and may show opportunistic feeding habits. However, climate conditions may influence the dolphin's feeding ecology because certain conditions may affect prey occurrence.

\section{MATERIALS AND METHODS}

\section{Study area and sampling}

We obtained 54 stomach samples of Guiana dolphins collected from stranded carcasses found along the southeastern coast of Brazil. The Guiana dolphin carcasses were found from Belmonte county $\left(15^{\circ} 52^{\prime} \mathrm{S}-38^{\circ} 51^{\prime} \mathrm{W}\right.$, Fig. 1) to Marataizes county $\left(21^{\circ} 04^{\prime} \mathrm{S}-40^{\circ} 50^{\prime} \mathrm{W}\right.$, Fig. 1). Our study area includes part of the Abrolhos Bank $\left(16^{\circ} 40^{\prime}-19^{\circ} 30^{\prime} \mathrm{S} ; 3^{\circ} 25^{\prime}-39^{\circ} 45^{\prime} \mathrm{W}\right)$, an extension of the Brazilian continental shelf ranging from southern Bahia State to the Rio Doce estuary (Muehe 2001). The Abrolhos Bank is a heterogeneous environment, holding several different types of habitat, including calcareous algae banks, soft bottoms, sandstone and coral reefs (Muehe 2001). The Abrolhos Bank features high biodiversity and has been classified as a marine hotspot (Dutra 2006). Oceanographically, oligotrophic waters of the Brazilian Current are predominantly found in our study area, though seasonal upwelling waters may occasionally come up off the southern Espírito Santo State coast (Schmid et al. 1995).

To collect the carcasses used for this study, we followed the recommendations of experts for stranding of marine mammals in Brazil from the Rede de encalhes de mamíferos marinhos do Brasil (REMAB). Two nongovernmental organizations, the Instituto Baleia Jubarte (IBJ) and the Instituto ORCA, were responsible for managing the Guiana dolphin carcasses. Diet composition was studied by examining stomach remains. Stomachs were dissected and hard structures were retrieved using tap water and a kit of graded-diameter net-size sieves. We considered both the maximum right or left otolith counted and the size of otoliths found in stomach contents to estimate the relative abundance of fish prey species. Cephalopod abundance was estimated using the maximum number of either upper or lower beaks found. All prey items found in Guiana dolphin stomachs were sorted, tagged and identified to the lowest possible taxonomic level. We identified fish preys using the sagittal otoliths based on available catalogues and guides (e.g. Corrêa and Vianna 1992, Baremore and Bethea 2010, Rossi-Wongtschowski et al. 2014). All alimentary items found in Guiana dolphin stomachs were archived in the Zoological Collection at the Federal University of Espírito Santo (CEUNES-UFES). Moreover, we classified the Guiana dolphin specimens 

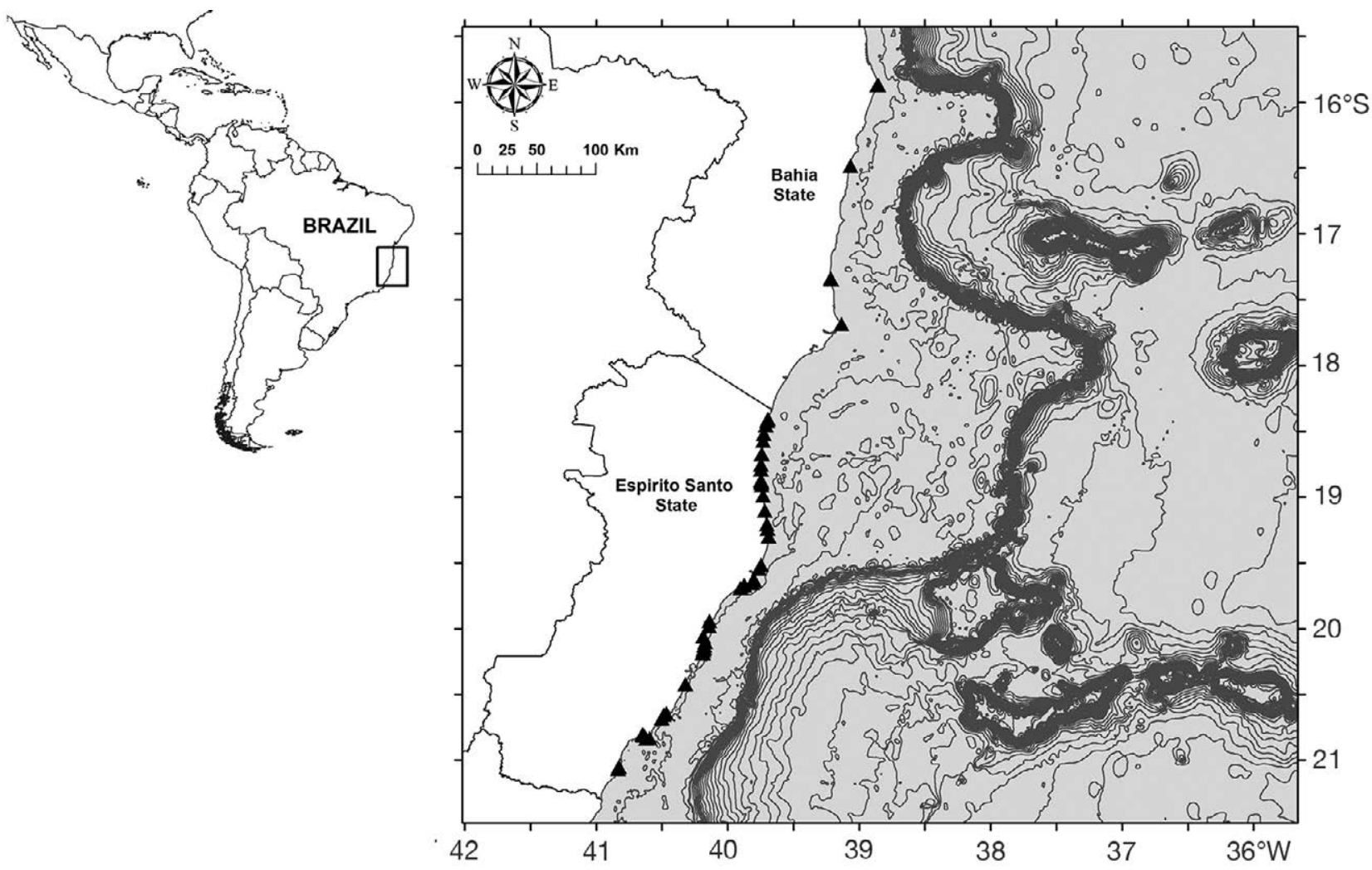

Fig. 1. - Study area shows sites in which stranded carcasses of Guiana dolphin (triangles) were found along a coastline ranging from the southern Bahia State to the southern Espirito Santo State, along the southeastern coast of Brazil. Collection acquired from June 2007 to April 2015.

by sex and age class (ontogenetic class). For ontogenetic classes, we adopted the criterion of body length, whereby males larger than $173 \mathrm{~cm}$ and females larger than $167 \mathrm{~cm}$ were classified as adults (Weber Rosas and Monteiro-Filho 2002).

\section{Data analysis}

To describe Guiana dolphins' diet, we used the frequency of occurrence of each type of prey within the overall spectrum of prey $(\% \mathrm{O})$. Among all dietary descriptors, we paid special attention to the frequency of occurrence, which expresses how often a certain type of prey was consumed by the predator (Cailliet 1977), enabling us to weight all specific predator-prey relationships from a bipartite perspective to the broadest extent. The frequency of occurrence is defined as the proportion of stomachs containing a specific prey item, expressed as a percentage. Additionally, we obtained the numerical abundance of prey species $(\% \mathrm{~N}$, also referred to as absolute abundance) and the relative abundance of prey species (\% P). These two measures are defined as (i) the proportion of all prey items for a prey taxon to the total count of prey individuals found in all predators; and (ii) the proportion of the total count for a specific prey to the total count of prey items found in all stomachs in which the type of prey occurs, respectively (Cortés 1997). We used the Costello (1990) graphical representation as a complementary method for showing the importance of the prey species composing the Guiana dolphin's diet.
We used two complementary approaches to compare the diet between males and females and between adults and juveniles. First, we tested likely differentiation through a multivariate analysis of variance (PERMANOVA) using the vegan package (Oksanen et al. 2013) with 999 permutations. Second, we used the Morisita index to estimate the trophic niche overlap between classes via the spaa package (Zhang 2016). These analyses were performed in R ( $\mathrm{R}$ Team 2017).

Moreover, we performed a multivariate regression tree to determine whether a set of candidate variables was able to explain differences in dietary composition among Guiana dolphin individuals (De'ath 2002). Regression trees aim to select variables amenable to grouping sampling units in a way in which groups are homogeneous and the differences between groups are maximized (Breiman et al. 1984). We included as predictors of prey variation among Guiana dolphin individuals the precipitation accumulated in the last month $(\mathrm{P} 1 \mathrm{M})$, the precipitation accumulated in the last three months (P3M), atmospheric temperature $(\mathrm{T})$ and sea surface temperature (SST). Temperature and rainfall variables were obtained from the available online database (INMET 2017), while SST values were obtained from the Ocean Motion (NASA 2017) online database. These climate data were chosen because there are exhibits showing that these variables could have crucial significance in defining the distribution of dolphins (Selzer and Payne 1988). We set the maximal tree size interactively by cross-validating the results, then using a minimal number of splits $>3$. To 
Table 1. - Quantitative descriptors of prey consumed by 54 Guiana dolphin (Sotalia guianensis) stranded individuals from the coasts of the southern Bahia State to the northern Espirito Santo State in Brazil. Acronyms of descriptors are as follows: O, frequency of occurrence; N, numerical abundance; $P$, relative abundance.

\begin{tabular}{|c|c|c|c|}
\hline Prey items & $\mathrm{O}(\%)$ & $\mathrm{N}(\%)$ & $\mathrm{P}(\%)$ \\
\hline \multicolumn{4}{|l|}{ Teleostei } \\
\hline Acanthuridae & 1.85 & 0.07 & 12.50 \\
\hline Acanthurus chirurgus (Bloch, 1789) & 1.85 & 0.07 & - \\
\hline Ariidae & 11.11 & 5.43 & 12.81 \\
\hline Bagre bagre (Linnaeus, 1758) & 11.11 & 4.98 & - \\
\hline Carangidae & 18.52 & 1.51 & 4.66 \\
\hline Chloroscombrus chrysurus (Linnaeus, 1766) & 7.41 & 0.69 & - \\
\hline Selene setapinnis (Mitchill, 1815) & 5.55 & 0.35 & - \\
\hline Selar crumenophthalmus (Bloch, 1793) & 1.85 & 0.07 & - \\
\hline Carangidae $\mathrm{Ni}$ & 3.70 & 0.28 & - \\
\hline Clupeidae & 18.52 & 1.73 & 9.2 \\
\hline Opisthonema oglinum (Lesueur, 1818) & 14.81 & 1.31 & - \\
\hline Sardinella $\mathrm{sp}$. & 3.70 & 0.28 & - \\
\hline Elopidae & 3.70 & 0.15 & 14.29 \\
\hline Elops saurus Linnaeus, 1966 & 3.70 & 0.14 & - \\
\hline Engraulidae & 44.44 & 12.22 & 18.02 \\
\hline Anchoa filifera (Fowler, 1915) & 1.85 & 0.07 & - \\
\hline Anchoa spinifera (Valenciennes, 1848) & 7.41 & 1.17 & - \\
\hline aff. Engraulis anchoita Hubbs and Marini, 1935 & 1.85 & 0.07 & - \\
\hline Lycengraulis grossidens (Agassiz, 1829) & 18.52 & 4.98 & - \\
\hline Engraulidae $\mathrm{Ni}$ & 31.5 & 4.91 & - \\
\hline Gerreidae & 12.96 & 1.73 & 4.03 \\
\hline Diapterus auratus Ranzani, 1840 & 3.70 & 0.28 & - \\
\hline Diapterus rhombeus (Valenciennes, 1830) & 1.85 & 0.83 & - \\
\hline Eugerres brasilianus (Valenciennes, 1830) & 7.41 & 0.48 & - \\
\hline Haemulidae & 31.48 & 17.12 & 32.99 \\
\hline Haemulon aurolineatum (Cuvier, 1830) & 3.70 & 0.83 & - \\
\hline Haemulon steindachneri (Jordan and Gilbert, 1982) & 1.85 & 9.40 & \\
\hline Haemulopsis corvinaeformis (Steindachner, 1868) & 7.41 & 0.48 & - \\
\hline Haemulidae $\mathrm{Ni}$ & 24.07 & 4.98 & - \\
\hline Hemirhamphidae & 1.85 & 0.15 & 8.00 \\
\hline Hemirhamphus brasiliensis (Linnaeus, 1758) & 1.85 & 0.07 & - \\
\hline Hyporhamphus unifasciatus (Ranzani, 1842) & 1.85 & 0.07 & - \\
\hline Lutjanidae & 3.70 & 0.23 & 5.45 \\
\hline Lutjanus analis (Cuvier, 1828) & 1.85 & 0.14 & - \\
\hline Lutjanus synagris (Linnaeus, 1758) & 1.85 & 0.14 & - \\
\hline Mugilidae & 5.56 & 0.38 & 16.67 \\
\hline Mugil spp. & 5.56 & 0.38 & \\
\hline Pleuronectiformes & 9.26 & 1.96 & 29.21 \\
\hline cf. Scyacium sp. & 3.70 & 0.14 & - \\
\hline cf. Paralichthys sp. & 3.70 & 1.38 & - \\
\hline Pleuronectiformes $\mathrm{Ni}$ & 7.41 & 0.28 & - \\
\hline Pristigasteridae & 27.78 & 5.66 & 9.78 \\
\hline Chirocentrodon bleekerianus (Poey, 1867) & 11.11 & 1.24 & - \\
\hline Pellona harroweri (Fowler, 1919) & 22.22 & 3.94 & - \\
\hline Sciaenidae & 50.00 & 47.06 & 68.50 \\
\hline Ctenosciaena gracilicirrhus (Metzelaar, 1919) & 7.41 & 0.28 & - \\
\hline Cynoscion jamaicensis (Vaillant and Bocourt, 1883) & 1.85 & 0.14 & - \\
\hline Cynoscion virescens (Cuvier, 1830) & 1.85 & 0.07 & - \\
\hline Isopisthus parvipinnis (Cuvier, 1830) & 33.33 & 6.63 & - \\
\hline Larimus breviceps Cuvier, 1830 & 18.52 & 2.97 & - \\
\hline Macrodon ancylodon (Bloch and Schneider, 1801) & 1.85 & 1.66 & - \\
\hline Micropogonias furnieri (Desmarest, 1823) & 1.85 & 0.14 & - \\
\hline Nebris microps Cuvier, 1830 & 3.70 & 0.41 & - \\
\hline Paralonchurus brasiliensis (Steindachner, 1875) & 5.55 & 2.07 & - \\
\hline Stellifer brasiliensis (Schultz, 1945) & 11.11 & 6.08 & - \\
\hline Stellifer $\mathrm{sp}$. & 22.22 & 22.53 & - \\
\hline Umbrina sp. & 1.85 & 0.14 & - \\
\hline Sparidae & 1.85 & 0.53 & 19.44 \\
\hline aff. Pagrus pagrus (Linnaeus, 1758) & 1.85 & 0.48 & - \\
\hline Sphyraenidae & 1.85 & 0.07 & 14.29 \\
\hline Sphyraena guachancho Cuvier, 1829 & 1.85 & 0.07 & - \\
\hline Trichiuridae & 31.48 & 3.77 & 7.38 \\
\hline Trichiurus lepturus Linnaeus, 1758 & 31.48 & 3.46 & - \\
\hline Crustacea & & & \\
\hline Dendrobranchiata & 1.85 & 0.23 & 2.19 \\
\hline Dendrobranchiata Ni & 1.85 & 0.21 & - \\
\hline Mollusca & & & \\
\hline Cephalopoda & & & \\
\hline Cephalopoda $\mathrm{Ni}$ & 37.04 & 8.22 & - \\
\hline Bivalva & & & \\
\hline Bivalva Ni & 3.70 & 0.14 & - \\
\hline
\end{tabular}


perform the regression tree analysis, we considered 42 sampling units, since SST data from 2015 were not available. We showed the resulting classification with a principal component analysis (PCA) (correlation) on Guiana dolphin individuals according to preference of prey species (De'ath 2002, Borcard et al 2011, De'ath 2014). The asymmetry of prey data was corrected using the Hellinger transformation (Legendre and Legendre 1998). We performed multivariate regression tree analyses in $\mathrm{R}$ ( $\mathrm{R}$ Team 2017) using the vegan (Oksanen et al. 2013) and mvpart (De'ath 2014) packages.

\section{RESULTS}

We collected 54 individuals stranded on shore in the study area from June 2007 to April 2015 (Fig. 1). Guiana dolphin sampling included 26 adults, 17 juveniles and 11 undetermined age class specimens. Moreover, among them we found 24 males, 13 females and 17 individuals of undetermined sex. Prey items found in their stomachs included fish, crustaceans, cephalopods and other molluscs (Table 1). However, otoliths features were occasionally eroded by the effect of stomach acids, and identification to species was not always possible. Overall, we counted 1447 prey items in stomach remains.

Our descriptive analysis of Guiana dolphin stomachs showed that bony fish occurred in all samples examined containing food remains $(100 \%$ O, Table 1) and covered $91.43 \%$ of all prey identified. Crustaceans occurred in only one sample $(1.85 \% \mathrm{O}$, Table 1$)$. We found cephalopods in 20 stomachs (37\% O, Table 1). Sciaenid fish species were the most common $(50 \% \mathrm{O})$

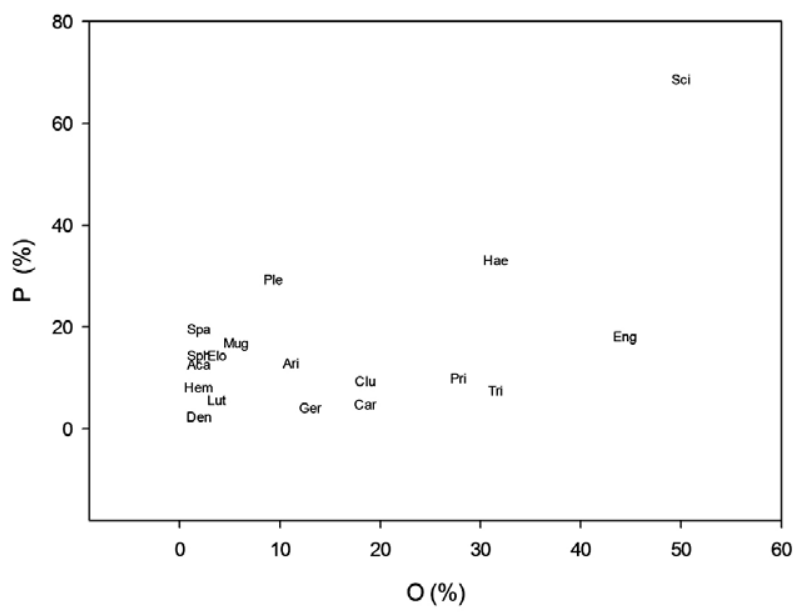

Fig. 2. - Costello graphical representation showing the relative importance and dominance of the prey. Axis X refers to the frequency of occurrence $(\mathrm{O})$ and axis $\mathrm{Y}$ to the specific prey relative abundance (P), both measures expressed as a percentage. Prey acronyms are as follows: Ari, Ariidae; Car, Carangidae; Clu, Clupeidae; Den, Dendrobranchiata; Elo, Elopidae; Eng, Engraulidae; Ger, Gerreidae; Hae, Haemulidae; Hem, Hemiramphidae; Lut, Lutjanidae; Mug, Mugilidae; Ple, Pleuronectiformes; Pri, Pristigasteridae; Sci, Sciaenidae; Spa, Sparidae; Sph, Sphyraenidae; Tri, Trichiuridae.

and most abundant (47\% N) type of prey consumed by the Guiana dolphin (Table 1). Twelve sciaenid species were identified in the stomachs, with Isopisthus parvipinnis most frequently found $(33 \% \mathrm{O}$, Table 1$)$. However, drums (Stellifer genus) were the most abundant prey items found $(22.5 \% \mathrm{~N}$, Table 1$)$. The graphical representation shows sciaenids to be the predominant type of prey consumed by the dolphins (Fig. 2). Moreo-
A

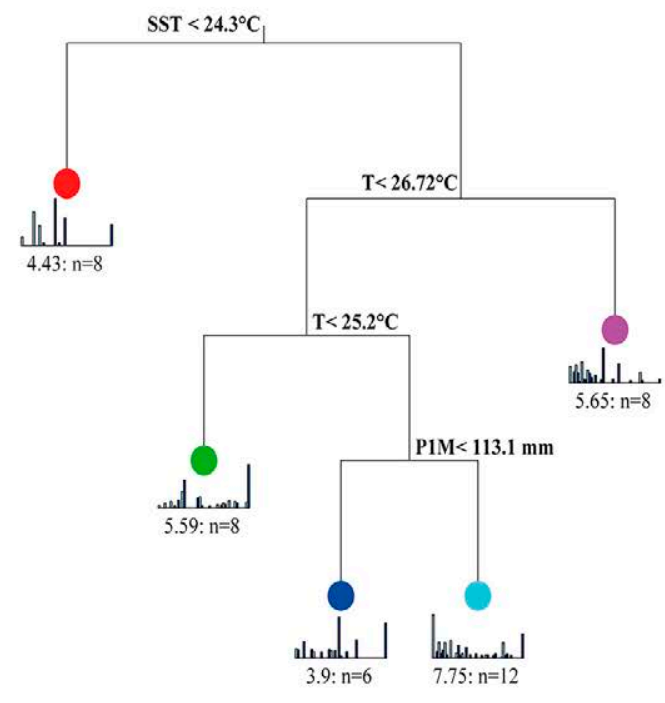

Error: 0.822 CV Error: 1.26 SE: 0.0644

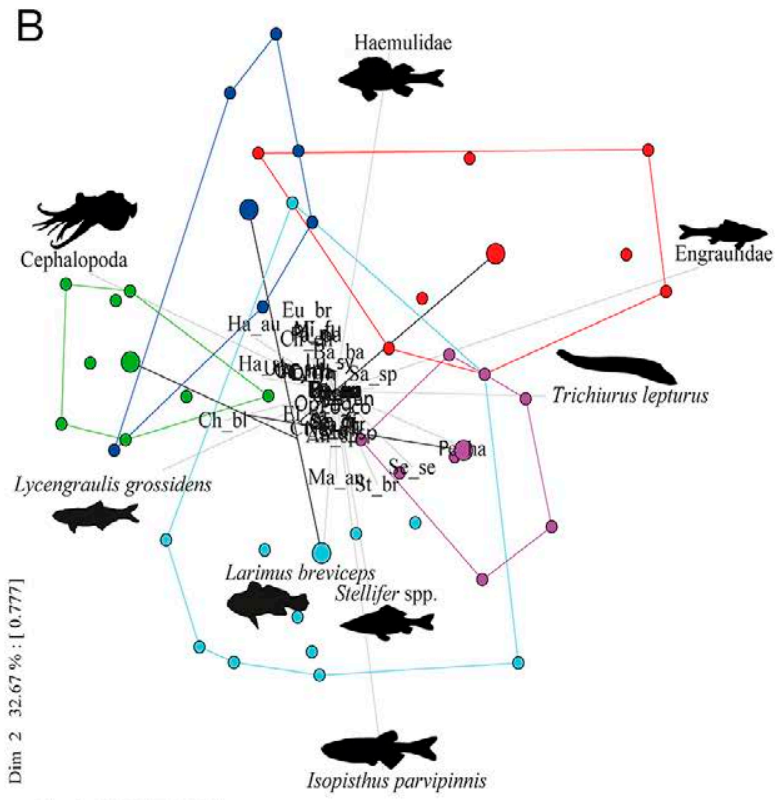

Dim 1 42.26\%: [0.818]

Fig. 3. - A, regression tree for responses in Guiana dolphin diet composition due to different thresholds of environmental conditions across the central Atlantic coast of Brazil. The bars below the final junctions represent changes in prey species, and height describes the probability of occurrence of each prey species in that particular environmental condition (i.e. proximity to a value of " 1 " and including hierarchical effects from superior groups) based on recursive partitioning of the regression tree. The order of species in the bars are in Table 2 . The values below the bars represent the similarity between all sampling units within the unfolding compared with a split with the same number of observations (N). B, principal component analysis spatially ordering the sample points and their prey species occurring under certain conditions, according to the junctions formed by regression tree analysis. Species name abbreviations in Table 2. 
Table 2. - Relative presence of Guiana dolphin prey as a function of changes in climate conditions for each group formed by the regression tree on the southern Atlantic coast of Brazil. See the meaning of the colour groupings in the legend of Figure 2A. Values in bold represent the highest probability of prey species occurrence from the regression tree grouping.

\begin{tabular}{|c|c|c|c|c|c|c|}
\hline $\begin{array}{l}\text { Leaf } \\
\text { Proportion explained } \\
\text { Taxonomic level }\end{array}$ & Abbrev. & $\begin{array}{l}\text { Red } \\
3.51\end{array}$ & $\begin{array}{l}\text { Pink } \\
3.89\end{array}$ & $\begin{array}{c}\text { Green } \\
2.31 \\
\text { Probabi }\end{array}$ & $\begin{array}{c}\text { Light blue } \\
4\end{array}$ & $\begin{array}{c}\text { Dark blue } \\
3.43\end{array}$ \\
\hline Isopisthus parvipinnis & Is_pa & 0.08 & 0.02 & 0.08 & 0.41 & 0.15 \\
\hline Micropogonias furnieri & Mi_fu & 0 & 0 & 0.08 & 0 & 0 \\
\hline Stellifer brasiliensis & St_b̄r & 0 & 0 & 0 & 0.06 & 0.11 \\
\hline Stellifer sp. & $\mathrm{St} \_$sp & 0 & 0.04 & 0 & 0.15 & 0.17 \\
\hline Bagre bagre & Ba_ba & 0 & 0 & 0.15 & 0.04 & 0.09 \\
\hline Macrodon ancylodon & Ma_an & 0 & 0 & 0 & 0.08 & 0.02 \\
\hline Trichiurus lepturus & Tr_le & 0.32 & 0.06 & 0 & 0.14 & 0.2 \\
\hline Mugil sp. & Mu_sp & 0 & 0 & 0 & 0.03 & 0.04 \\
\hline Pleuronectiformes $\mathrm{Ni}$ & Pl_ni & 0 & 0.02 & 0.08 & 0 & 0.03 \\
\hline Pellona harroweri & Pe_ha & 0.19 & 0 & 0.06 & 0.16 & 0.12 \\
\hline Opisthonema oglinum & Op_og & 0 & 0.07 & 0 & 0 & 0.09 \\
\hline Sardinella sp. & Sa_sp & 0.03 & 0 & 0 & 0 & 0.05 \\
\hline Chirocentrodon bleekerianus & Ch_bl & 0 & 0.15 & 0 & 0.05 & 0 \\
\hline Lycengraulis grossidens & Ly_gr & 0 & 0.26 & 0.06 & 0.12 & 0.07 \\
\hline Anchoa filifera & An_fi & 0 & 0 & 0 & 0.03 & 0 \\
\hline Anchoa spinifera & An_sp & 0 & 0 & 0 & 0.04 & 0 \\
\hline Engraulis anchoita & En_an & 0 & 0 & 0 & 0 & 0.03 \\
\hline Engraulidae Ni & En_ni & 0.44 & 0 & 0.08 & 0.1 & 0.33 \\
\hline Pagrus pagrus & Pa_pa & 0 & 0 & 0.07 & 0 & 0 \\
\hline Pomadasys corvinaeformis & Po_co & $\mathbf{0 . 0 3}$ & 0 & 0 & 0.03 & 0 \\
\hline Haemulon aurolineatum & Ha_au & 0 & 0.09 & 0.07 & 0 & 0 \\
\hline Haemulon steindachneri & Ha_st & 0 & 0.1 & 0 & 0 & 0 \\
\hline Haemulidae Ni & Ha_ni & 0.26 & 0.02 & 0.38 & 0.04 & 0.04 \\
\hline Lutjanus synagris & Lu_sy & 0 & 0 & 0.02 & 0 & 0 \\
\hline Lutjanus analis & Lu_an & 0 & 0 & 0 & 0 & 0 \\
\hline Selene setapinnis & Se_se & 0 & 0 & 0 & 0.03 & 0.18 \\
\hline Chloroscombrus chrysurus & Ch_ch & 0 & 0.02 & 0.06 & 0 & 0 \\
\hline Selar crumenophthalmus & $\mathrm{Se} \_\mathrm{cr}$ & 0 & 0 & 0 & 0.03 & 0 \\
\hline Carangidae $\mathrm{Ni}^{i}$ & Ca_ni & 0 & 0 & 0 & 0.03 & 0 \\
\hline Diapterus auratus & Di_au & 0 & 0 & 0 & 0 & 0 \\
\hline Diapterus rhombeus & Di_rh & 0 & 0.03 & 0 & 0 & 0 \\
\hline Eugerres brasilianus & Eu_br & 0 & 0 & 0.17 & 0.03 & 0.02 \\
\hline Ctenosciaena gracilicirrhus & Ct_gr & 0 & 0.03 & 0 & 0.04 & 0 \\
\hline Acanthurus chirurgus & Ac_ch & 0 & 0.04 & 0 & 0 & 0 \\
\hline Cynoscion jamaicensis & $\mathrm{Cy}_{-} \mathrm{ja}$ & 0 & 0.03 & 0 & 0 & 0 \\
\hline Cynoscion virescens & Cy_vi & 0 & 0 & 0 & 0 & 0 \\
\hline Larimus breviceps & La_br & 0 & 0.07 & 0 & 0.14 & 0.1 \\
\hline Paralonchurus brasiliensis & $\mathrm{Pa} \_$br & 0 & 0 & 0 & 0.02 & 0.03 \\
\hline Nebris microps & Ne_mi & 0 & 0 & 0 & 0.04 & 0 \\
\hline Umbrina sp. & Um_sp & 0 & 0.06 & 0 & 0 & 0 \\
\hline Elops saurus & $\mathrm{El} \_\mathrm{sa}$ & 0 & 0.04 & 0 & 0.03 & 0 \\
\hline Sphyraena guachancho & Sp_gu & 0 & 0 & 0 & 0 & 0 \\
\hline Hemirhamphus brasiliensis & He_br & 0 & 0 & 0 & 0 & 0 \\
\hline Hyporhamphus unifasciatus & Hy_un & 0 & 0 & 0 & 0 & 0 \\
\hline Dendrobranchiata Ni & Den & 0 & 0 & 0 & 0 & 0 \\
\hline Gasteropoda Ni & Ga_ni & 0 & 0.05 & 0 & 0 & 0 \\
\hline Cephalopoda Ni & Ce_ni & 0.2 & 0.4 & 0.33 & 0.23 & 0.04 \\
\hline
\end{tabular}

ver, this representation shows the importance of pelagic preys too, such as those species in the Clupeiformes order and Trichiurus lepturus. Haemulids (reef fish) have also been common prey consumed by Guiana dolphins (Fig. 2, Table 1). Additionally, Elops saurus occurred in two samples, an adult male and an adult female, collected from two nearby sites in April and August 2012, respectively. Both Hemirhamphus brasiliensis and $\mathrm{Hy}$ porhamphus unifasciatus were singletons occurring in the same sample. The sample corresponded to an adult individual, whose sex could not be determined, and it was collected in April 2015 on a Prado County beach, southern Bahia State.

We detected no differentiation in dietary patterns or diet composition between classes between either males and females or adults and juveniles. Our analysis showed no significant difference in diet composition between males and females [Fmodel=1.03; p >0.05].
However, the Morisita trophic niche overlap index showed a rather high estimate [Observed $=0.89$; Bootstrap mean=0.88; Boot std=0.04; Boot CI1=0.80; Boot $\mathrm{CI} 2=0.95$, times $=999]$. We also found no significant differences in diet composition between adults and juveniles [Fmodel=0.99; $\mathrm{p}>0.05]$. For this comparison, the Morisita trophic niche overlap measure also showed a rather high estimate $[$ Observed $=0.86$; Bootstrap mean=0.85; Boot std=0.03; Boot CI1=0.78; Boot CT2=0.91; times $=999]$.

The regression tree analysis explained $17.13 \%$ of total variation among Guiana dolphin diet in relation to environmental predictors [Error $=0.822 ; \mathrm{CV}$ error $=1.26, \mathrm{SE}=0.06]$. The leaf $\mathrm{n}^{\circ} 1$ (red) explained $3.51 \%$ of the data variance and was linked to SST lower than $24.3^{\circ} \mathrm{C}$. In these conditions, the main prey was Trichiurus lepturus (Fig. 3A, Table 2). The lower leaf $\left(\mathrm{n}^{\circ} 2\right.$, pink) explained another $3.89 \%$ of the overall var- 
iation of dolphin diet. With conditions of SST higher than $24.3^{\circ} \mathrm{C}$ and $\mathrm{T}$ higher than $26.72^{\circ} \mathrm{C}$, the main prey eaten by Guiana dolphins were cephalopods (Fig. 3A, Table 2). The following leaf ( $\mathrm{n}^{\circ} 3$, green) explained $2.32 \%$ of the variation, linked to a temperature ranging from $25.2^{\circ} \mathrm{C}$ to $26.72^{\circ} \mathrm{C}$. In these conditions, the main prey was Bagre bagre. The remaining leafs ( ${ }^{\circ} 4$ (light blue) and $n^{\circ} 5$ (dark blue)) explained together $7.43 \%$ of data variation. In leaf $n^{\circ} 4$, the main prey consumed was I. parvipinnis and in $\mathrm{n}^{\circ} 5$ it was Engraulids (Fig. $3 \mathrm{~A}$, Table 2). The ordination (PCA) subsequent to the regression tree explained $74.93 \%$ of data variation and showed the grouping around the main prey of Guiana dolphins according to spatiotemporal climate conditions (Fig. 3B).

\section{DISCUSSION}

Understanding species food habits is a paramount issue in ecology (Miller and Payne 1964, Pianka 1974, Pianka and Jorgensen 2008). Our main findings showed a large plasticity in the Guiana dolphin diet, with variations associated with climate features. Our results are also in agreement with previous studies on Guiana dolphin diet in Brazil (Lopes et al. 2012) and showed that the dolphins could prey on different functional prey species through the water column (Borobia and Barros 1989). Demersal, pelagic, neritic fishes (such as those in the Pleuronectiformes order) and cephalopods were common prey found in Guiana dolphin stomachs from the southeast coast of Brazil. Our findings agree with those of previous studies and show sciaenid fish species as the most common prey consumed by the Guiana dolphin (Lopes et al. 2012). However, pelagic species have also been reported as the most important fish consumed by the southern Guiana dolphin populations in Brazilian waters (Simões-Lopes 1988, Daura-Jorge et al. 2011, Cremer et al. 2012).

Moreover, the diet of this small-bodied cetacean seems to vary geographically and must be closely linked to the abundance and availability of prey in shallow waters. This pattern has been described in studies about small-bodied delphinids (Selzer and Payne 1988, Barros et al. 1990). The diet of the Guiana dolphin described in our study was very similar to that found by Rodrigues (2014), which showed sciaenid fish and coastal squids as extremely important prey for the Guiana dolphin on the central coast of Brazil. Along the northeastern coast of Brazil, haemulid fish were predominant prey for the Guiana dolphin (Pansard et al. 2011), while on the Rio de Janeiro coast Atlantic Midshipman fish was an important prey for this dolphin (Di Beneditto and Ramos 2004). Given that the species is a homeothermic top predator, the Guiana dolphin is likely a key species in those ecosystems in which the species occurs (Bowen 1997). Thus, this regional knowledge about diet and feeding ecology of Guiana dolphins is a valuable tool for the purpose of conservation biology.

We found noteworthy that the sciaenid I. parvipinnis was the most frequent fish predated by the Guiana dolphin in the study area. Isopisthus parvipinnis, known locally as pescadinha, is an economically key resource (Froese and Pauly 2017) and a major harvest for many fishing communities along the central coast of Brazil (Menezes and Figueiredo 1980). Moreover, this fish species is the most frequent prey consumed by Pontoporia blainvillei (Gervais and D'orbigny, 1844), which is a sympatric dolphin (Rupil 2016). These aforementioned issues (i.e. overfishing and interspecific trophic overlap with other sympatric marine mammals) suggest that the Guiana dolphins could be vulnerable, given that I. parvipinnis is likely to decline dramatically by over-exploitation as a result of trophic overlap along fisheries, the Guiana dolphins and other sympatric marine mammals (Rupil 2016). We encourage further studies to consider fish prey size in order to obtain better estimates of trophic overlap between coexisting top predators (Bittar and DiBeneditto 2009).

Regarding sex and age class comparisons, the multivariate and univariate approaches used to compare diet between classes of dolphins were consistent. We have no evidence on any possible trophic differentiation. However, we suggest that further studies should consider stable isotope techniques to unveil otherwise concealed differentiation patterns in diet composition (Di Beneditto and Monteiro 2016).

Our findings suggest that the diet composition of dolphins may show non-random geographical variation. The particular case of the two occurrences of $E$. saurus and the case of those hemiramphid singletons also provide support to our statement. Furthermore, Elops saurus is a pelagic fish species that feeds primarily on crustaceans and small fish (Barletta and Corrêa 1992), while both $H$. brasiliensis and $H$. unifasciatus are reef-associated omnivorous fish species that feed on algae and other small animals (Froese and Pauly 2017). Thus, our study provides evidence on the functional plasticity of the Guiana dolphin in the ecosystems that the species inhabits, suggesting a resource sharing among populations. It seems that the ecological role of the Guiana dolphin occupies a large functional spectrum throughout the species' distribution. Our results also provide new records of prey species consumed by the Guiana dolphin in Brazil: Acanthurus chirurgus, Pagrus pagrus and Selar crumenophthalmus. Finally, our findings demonstrate the significance of dietary studies of marine mammals for unveiling potential predator-prey relationships.

Changes in environmental conditions can influence the distribution of some prey species (Rodríguez Roda 1955), leading to a directional change in the availability of food items for top predators in marine ecosystems (Montevecchi and Myers 1997). Accordingly, our results showed that some environmental conditions could lead to non-random shifts in Guiana dolphin diet. SST is the strongest predictor, followed by temperature and monthly cumulative rainfall. These conditions influenced which specific prey the Guiana dolphin was consuming across our study area. Among the main Guiana dolphin prey, we observed a possible turnover among Trichiurus lepturus, squids, Bagre bagre, I. parvipinnis and engraulids, depending on environmental conditions. For instance, T. lepturus appeared 
to be more abundant at the lowest SST, in agreement with previous studies indicating that the optimal water temperature for these fish is from $20^{\circ} \mathrm{C}$ to $24^{\circ} \mathrm{C}$ (Kao et al. 2015). In terms of the number of samples defining the groups and the amount of variation explained by groups, we can observe in the regression tree analysis and in the ordination analysis that leaf $n^{\circ} 4$ and leaf $n^{\circ}$ 5 were the dominant groups of Guiana dolphin prey.

The main prey species that made up leaf $n^{\circ} 4$ and leaf $n^{\circ} 5$ in the regression tree were sciaenids and engraulids, which are the most frequent prey species found in Guiana dolphin stomach remains. The environmental conditions that weighted most for grouping the aforementioned groups (leaf on regression tree) were high SST, intermediate atmospheric temperature and high monthly rainfall. These climatic conditions typically feature some environments used by several fish prey species as nursery areas (Ansari et al. 1995, BarlettaBergan et al. 2002). Rainfall plays an important role in the availability of food resources for dolphins because it relates to salinity in estuarine environments, which in turn influences the structure of fish assemblages (Selzer and Payne 1988, Barletta et al. 2005). Our results also support previous evidence on the major effect of SST on the distribution of fish species across the southwestern Atlantic (Floeter et al. 2005).

The regression tree supports - at least partiallythe plasticity of the Guiana dolphin diet along the Brazilian coast in relation to climatic conditions. It is difficult to unravel the role of prey availability and intra- and interspecific competition as a causal driver of dietary behaviour or as a coexisting complement mediated by climate. Both climate and physicochemical conditions govern the productivity of ecosystems in both terrestrial and marine ecosystems (Nemani et al. 2003, Pan et al. 2016). We recognize that a single model considering the climate variability represents only a portion of the aquatic ecosystem complexity.Moreover, the coastal marine ecosystem receives several impacts from adjacent terrestrial areas, from climate to anthropogenic eutrophication, making the dynamics and diversity patterns of biotic communities change spatiotemporally (Morales-Ojeda et al. 2010). Consequently, even dietary variations at the individual level can be expected under these conditions. However, this variation in diet composition of predators has been taken into consideration in previous studies. For example, Olson and Waters (2003) assumed changes in diet as a function of climate variability to construct a pelagic Eastern Pacific Ocean ecosystem model.

We recognize that some methodological shortcomings related to the stomach content examination method may introduce a bias in the estimation of relative importance for some prey species. The importance of species featuring relatively large and robust otoliths in the stomach remains could be overestimated due to the erosive effects of stomach acids (Corrêa and Vianna 1992, Sekiguchi and Best 1997). The occurrence and abundance of cephalopods in the diet of dolphins could be overestimated since cephalopod beaks tend to accumulate in the dolphin stomachs, given differentials in digestion rates between prey (Sekiguchi and Best
1997). In this instance, we did not include squid in our graphical representation.

Furthermore, we recognize that non-climate datasets, such as characteristics of the seafloor and depth, influence the availability of food resources and per se define the Guiana dolphin distribution. However, our study rather supports previous evidence on the possible relation of climate data to the distribution of Guiana dolphins. We consider that adding non-climate data would enhance our understanding of the actual relations between environmental traits and the Guiana dolphin diet. We can conclude that the seminal characteristic feeding plasticity of the Guiana dolphin may be related to likely changes in climate conditions, given the capability of the Guiana dolphins to feed on a large spectrum of prey. Our primary finding showed that conditions typically found in estuaries correlate most with some of the most frequent prey species consumed by the dolphin. From a conservation ecology perspective, we conclude that estuaries-even ones that are overdepleted and succumbing to human impacts-might be paramount environments for the Guiana dolphin, serving as an important source of prey for this species and other sympatric marine mammals. Unfortunately, several strong, seminal pieces of evidence suggest that the human impact on marine ecosystems leads to a modern collapse of marine biota (Jackson et al. 2001). Thus, our findings may have implications for climate change and the conservation of marine mammals. We believe that our study will serve as the basis for new studies on the feeding ecology of the Guiana Dolphin and other marine and terrestrial predators in Brazil and elsewhere.

\section{ACKNOWLEDGEMENTS}

We are grateful to Dr. Maurício Eduardo Graipel and Vitor Leonardo Amaral Rodrigues for their kind support. Olímpio Rafael Cardoso assisted in the construction of the map. The cetacean rescue programme was carried out as required by federal environmental licensing of the Terminal Marítimo de Belmonte-BA, conducted by IBAMA. Stranded cetaceans were collected through license ICMBio 13306-6. We thank Adriana Colosio for conducting necropsies and screening the samples used in this work. We thank two anonymous reviewers for their valuable contribution to improving our manuscript. We thank Dr Steven Sharkey and Mrs Julie Wilson, B.A, Dip Ed. (Sydney University) for proofreading our manuscript. This study was financed in part by the Coordenação de Aperfeiçoamento de Pessoal de Nível Superior (CAPES), Brazil, Finance Code 001. JAB is supported by a postdoctoral fellowship grant 2018-05970-1, São Paulo Research Foundation (FAPESP). GMR is supported by a CAPES graduate scholarship grant (201700939).

\section{REFERENCES}

Ansari A., Chatterji A., Ingole B.S. 1995. Community Structure and Seasonal Variation of an Inshore Demersal Fish. Community at Goa, West Coast of India. Estuar. Coast. Shelf Sci. 41: 593-610. https://doi.org/10.1016/0272-7714(95)90029-2 
Baremore I.E., Bethea D.M. 2010. A guide to otoliths from fishes of the Gulf of Mexico. NOAA Technical Memorandum NMFS SEFSC- 599: 1-106.

Barletta M., Corrêa M.F.M. 1992. Guia para identificação de peixes da costa do Brasil. Editora UFPR, Curitiba, Brazil.

Barletta M., Barletta-Bergan A., Saint-Paul U., et al. 2005. The role of salinity in structuring the fish assemblages in a tropical estuary. J. Fish. Biol. 66: 45-72. https://doi.org/10.1111/j.0022-1112.2005.00582.x

Barletta-Bergan A., Barletta M., Saint-Paul U. 2002. Structure and seasonal dynamics of larval fish in the Caeté River Estuary in North Brazil. Estuar. Coast. Shelf Sci. 54: 193-206. https://doi.org/10.1006/ecss.2001.0842

Barros N.B., Odell D.K., Patton G.W. 1990. Ingestion of plastic debris by stranded marine mammals from Florida. In: Proceedings of the Second International Conference on Marine Debris. NOAA Tech. Memo. NOAA-TM-NMFS-SWFSC-154, 746 pp.

Bittar V.T., Di Beneditto A.P.M. 2009. Diet and potential feeding overlap between Trichiurus lepturus (Osteichthyes: Perciformes) and Pontoporia blainvillei (Mammalia: Cetacea) in Northern Rio de Janeiro. Brazil. Zool. (Curitiba, Impresso) 26: 374-378.

https://doi.org/10.1590/S1984-46702009000200023

Borcard D., Gillet F., Legendre P. 2011. Numerical ecology with R. Springer Science \& Business Media. https://doi.org/10.1007/978-1-4419-7976-6

Borobia M., Barros N.B. 1989. Notes on the diet of marine Sotalia fluviatilis. Mar. Mammal. Sci. 5: 395-399. https://doi.org/10.1111/j.1748-7692.1989.tb00353.x

Bowen W.D. 1997. Role of marine mammals in aquatic ecosystems. Mar. Ecol. Prog. Ser. 158: 267-274 https://doi.org/10.3354/meps158267

Breiman L., Friedman J.H., Olshen R.A., et al. 1984. Classification and Regression Trees. Chapman \& Hall/CRC eds.

Cailliet G.M. 1977. Several approaches to the feeding ecology of fishes. In: Simenstad C.A., Lipovsky S.J., Fish Food Habits Studies: Proceedings of the 1st Pacific Northwest Technical Workshop. Washington Sea Grant publication. Washington Sea Grant Program, Univ. Washington, Seattle, Wash. pp. 1-13.

Corrêa M.F.M., Vianna M.S. 1992. Catálogo de otólitos de Sciaenidae (Osteichthyes Perciformes) do litoral do estado do Paraná, Brasil. Neritica 7: 13-41.

Cortés E. 1997. A critical review of methods of studying fish feeding based on analysis of stomach contents: application to elasmobranch fishes. Can. J. Fish. Aquat. Sci. 54: 726-738. https://doi.org/10.1139/f96-316

Costello M.J. 1990. Predator feeding strategy and prey importance: a new graphical analysis. J. Fish. Biol. 36: 261-263. https://doi.org/10.1111/j.1095-8649.1990.tb05601.x

Cremer M.J., Pinheiro P.C., Simões-Lopes P.C. 2012. Prey consumed by Guiana dolphin Sotalia guianensis (Cetacea, Delphinidae) and franciscana dolphin Pontoporia blainvillei (Cetacea, Pontoporiidae) in an estuarine environment in southern Brazil. Iheringia Série Zool. 102: 131-137. https://doi.org/10.1590/S0073-47212012000200003

Da Silva V.M.F., Best R.C. 1996. Sotalia fluviatilis. Mamm. Species 527: 1-7. https://doi.org/10.2307/3504117

Daura-Jorge F.G., Wedekin L.L., Simões-Lopes P.C. 2011. Feeding habits of the Guiana dolphin, Sotalia guianensis (Cetacea: Delphinidae), in Norte Bay, southern Brazil. Sci. Mar. 75: 163-169. https://doi.org/10.3989/scimar.2011.75n1163

De'ath G. 2002. Multivariate regression trees: a new technique for modeling species-environment relationships. Ecology 83: 1105-1117. https://doi.org/10.2307/3071917

De'ath M.G. 2014. mvpart Multivariate partitioning. R Package.

Di Beneditto A.P.M., Monteiro L.R. 2016. Isotopic niche of two coastal dolphins in a tropical marine area: specific and age class comparisons. J. Mar. Biol. Assoc. U.K. 96: 853-858. https://doi.org/10.1017/S0025315415001095

Di Beneditto A.P.M., Ramos R.M.A. 2004. Biology of the marine tucuxi dolphin (Sotalia fluviatilis) in south-eastern Brazil. J. Mar. Biol. Assoc. U. K., 84: 1245-1250. https://doi.org/10.1017/S0025315404010744h

Di Beneditto A.P.M., Siciliano S. 2007. Stomach contents of the marine tucuxi dolphin (Sotalia guianensis) from Rio de Janeiro, south-eastern Brazil. J. Mar. Biol. Assoc. U.K. 87: 253-254 https://doi.org/10.1017/S0025315407053647

Dutra G.F., Allen G.R., Werner T., et al. 2006. A rapid marine biodiversity assessment of the Albrolhos Bank, Bahia, Brazil. Center for Applied Biodiversity Science (CABS).

Floeter S.R., Behrens M.D., Ferreira C.E.L., et al. 2005. Geographical gradients of marine herbivorous fishes: Patterns and processes. Mar. Biol. 147: 1435-1447.

https://doi.org/10.1007/s00227-005-0027-0

Flores P.A.C., Da Silva V.M.F. 2009. Tucuxi and Guiana Dolphin: Sotalia fluviatilis and S. guianensis. In: Encyclopedia of Marine Mammals (2n. ed.). Elsevier, pp. 1188-1192.

Froese R., Pauly D. (eds). 2017. FishBase. Accessed 21 Sept. 2017. http://www.fishbase.org

Instituto Nacional de Meteorologia, Brazil (INMET). 2017. Accessed 21 Sept. 2017. http://www.inmet.gov.br

Jackson J.B.C., Kirby M.X., Berger W.H., et al. 2001. Historical Overfishing and the Recent Collapse of Coastal Ecosystems. Science 293: 629-638. https://doi.org/10.1126/science.1059199

Kao W-Y., Tomiyasu M., Takahashi R., et al. 2015. Spatial and temporal distribution of hairtail (Trichiurus japonicus) in the Bungo Channel, Japan. J. Mar. Acoust. Soc. Japan 42: 167-176. https://doi.org/10.3135/jmasj.42.167

Legendre P., Legendre L. 1998. Numerical ecology. 2nd English Edition, Elsevier, Amsterdam.

Lopes X.M., Da Silva E., Bassoi M., et al. 2012. Feeding habits of Guiana dolphins, Sotalia guianensis, from south-eastern Brazil: new items and a knowledge review. J. Mar. Biol. Assoc. U.K. 92: $1723-1733$ https://doi.org/10.1017/S0025315412000495

Menezes N.A., Figueiredo J.D. 1980. Manual de peixes marinhos do sudeste do Brasil IV Teleostei (3). Univ. São Paulo, Museu de Zoologia.

Miller D.S., Payne P.R. 1964. Dietary factors influencing nitrogen balance. Proc. Nutr. Soc. 23: 11-19. https://doi.org/10.1079/PNS19640005

Montevecchi W.A., Myers R.A. 1997. Centurial and decadal oceanographic influences on changes in northern gannet populations and diets in the north-west Atlantic: Implications for climate change. ICES J. Mar. Sci. 54: 608-614. https://doi.org/10.1006/jmsc.1997.0265

Morales-Ojeda S.M., Herrera-Silveira J.A., Montero J. 2010. Terrestrial and oceanic influence on spatial hydrochemistry and trophic status in subtropical marine near-shore waters. Water Res. 44: 5949-5964. https://doi.org/10.1016/j.watres.2010.07.046

Muehe D. 2001. O litoral brasileiro e sua compartimentação. In: Cunha S.B., Guerra A.J. (ed.) Geomorfologia do Brasil. Bertrand Brasil, Rio de Janeiro, pp. 273-349.

NASA. 2017. Ocean Motion. Accessed 21 Sept. 2017. http://www.oceanmotion.org/html/resources/ssedv.htm

Nemani R.R., Keeling C.D., Hashimoto H., et al. 2003. Climatedriven increases in global terrestrial net primary production from 1982 to 1999 . Science 300: 1560-1563. https://doi.org/10.1126/science.1082750

Oksanen J., Blanchet F.G., Kindt R., et al. 2013. vegan Community Ecology Package, version 2

Olson R.J., Waters G.M. 2003. A model of the pelagic ecosystem in the eastern tropical Pacific Ocean. Inter-American Tropical Tuna Commission Bull. 22: 135-218.

Pan C.W., Chen M.H., Chou L.S., et al. 2016. The trophic significance of the indo-pacific humpback dolphin, Sousa chinensis, in Western Taiwan. PLoS One 11: 1-19. https://doi.org/10.1371/journal.pone.0165283

Pansard K.C.A., Gurgel H. de C.B., Andrade L.C. de A., et al. 2011. Feeding ecology of the estuarine dolphin (Sotalia guianensis) on the coast of Rio Grande do Norte, Brazil. Mar. Mammal Sci. 27: 673-687. https://doi.org/10.1111/j.1748-7692.2010.00436.x

Pauly D., Trites A.W., Capuli E., et al. 1998. Diet composition and trophic levels of marine mammals. ICES J. Mar. Sci. 55: 467-481 https://doi.org/10.1006/jmsc.1997.0280

Pianka E.R. 1974. Niche overlap and diffuse competition. Proc. Natl. Acad. Sci. USA 71: 2141-2145. https://doi.org/10.1073/pnas.71.5.2141

Pianka E.R., Jorgensen S.E. 2008. Optimal foraging. Encycl. Ecol. 2559-2561.

R Team. 2017. R: A language and environment for statistical computing. Vienna, Austria.

Rodrigues V.L.A. 2014. Dieta e ecologia alimentar do boto-cinza, Sotalia guianensis (Cetartiodactyla: Delphinidae), na região do 
Banco dos Abrolhos, costa central do Brasil. MSc dissertation, Universidade Federal do Espírito Santo (UFES), Brazil, 41 pp.

Rodríguez Roda J. 1955. Datos climáticos del puerto de Castellón y térmicos de las aguas costeras superficiales en relación con la pesca, en 1953. Inv. Pesq. 1: 3-15.

Rossi-Wongtschowski C.L.D.B., Siliprandi C.C., Brenha M.R., et al. 2014. Atlas of marine bony fish otoliths (sagittae) of southeastern- southern Brazil Part I: Gadiformes (Macrouridae, Moridae, Bregmacerotidae, Phycidae and Merlucciidae); Part II: Perciformes (Carangidae, Sciaenidae, Scombridae and Serranidae). Brazilian J. Oceanogr. 62: 1-103.

Rupil G.M. 2016. Dieta de golfinhos e sobreposição trófica com a pesca de arrasto na costa central do Brasil. MSc dissertation, Universidad Federal do Espírito Santo (UFES), Brazil, 51 pp.

Sekiguchi K., Best P.B. 1997. In vitro digestibility of some prey speciesof dolphins. Fish. Bull. 95: 386-393.

Selzer L.A., Payne P.M. 1988. The distribution of white-sided (Lagenorhynchus acutus) and common dolphins (Delphinus delphis) vs. environmental features of the continental shelf of the northeastern United States. Mar. Mammal Sci. 4: 141-153. https://doi.org/10.1111/j.1748-7692.1988.tb00194.x

Simões-Lopes P.C. 1988. Ocorrência de uma população de Sotalia fluviatilis (Gervais, 1853) (Cetacea, Delphinidae) no limite sul de sua distribuição, Santa Catarina, Brasil. Biotemas 1: 57-62.

Schmid C., Schäfer H., Zenk W., et al. 1995. The Vitória eddy and its relation to the Brazil Current. J. Phys. Oceanogr. 25: 2532-2546.

https://doi.org/10.1175/1520-0485(1995)025<2532:TVEAIR> 2.0.CO;2

Weber Rosas F.C., Monteiro-Filho E.L.A. 2002. Reproduction of the estuarine dolphin (Sotalia guianensis) on the coast of Paraná, southern Brazil. J. Mammal. 83: 507-515. https://doi.org/10.1644/1545-1542(2002)083<0507:ROTEDS> 2.0.CO;2

Zhang J. 2016. Species Association Analysis ‘spaa'. R package. https://github.com/helixcn/spaa 